\title{
THE LAST, SWEET-PICKLED PEAR
}

dissolves at the bottom

of the jar like some

tropical fish

in heavy thick-

sugar syrup.

In the sterile-bright enamel light of the refrigerator this pear is no grand inquisitor.

I do not answer, Water is $90 \%$ of every man.

I think of the gray canvas strap of the pickingsack worn across a migrant worker's shoulder,

of sweat pressed through the fabric of his shirt,

of wasps droning over windfallen fruit in the sun,

of new wine drunk as the man rocks with his body and its uses I cannot explain. 
Sometimes, perhaps, it is true, enough is never enough. Perhaps this pear was picked by machine

or even now the man is losing his balance and knows when he falls no branch will stop him.

He will never repeat his joke of the midwife of pears.

Sometimes, I think, tightening the lid is always what happens; I could say in its grief

this pear could weep; though, who could tell such a lie without shame? 
